\title{
Bibliographie de Robert Leonard Carneiro
}

\section{Monica Barnes et Philippe Erikson}

\section{OpenEdition}

Journals

Édition électronique

URL : https://journals.openedition.org/jsa/18843

DOl : $10.4000 /$ jsa. 18843

ISSN : 1957-7842

\section{Éditeur}

Société des américanistes

\section{Édition imprimée}

Date de publication : 15 décembre 2020

Pagination : 245-257

ISSN : 0037-9174

\section{Référence électronique}

Monica Barnes et Philippe Erikson, «Bibliographie de Robert Leonard Carneiro », Journal de la Société des américanistes [En ligne], 106-2 | 2020, mis en ligne le 30 décembre 2020, consulté le 16 septembre 2022. URL : http://journals.openedition.org/jsa/18843 ; DOI : https://doi.org/10.4000/jsa.18843 


\title{
Bibliographie de Robert Leonard Carneiro
}

\author{
établie par Monica BARNES \\ et Philippe ERIKSON *
}

\section{Ouvrages}

1979 Heta Indians. Fish in a Dry Pond, co-signé avec Vladimir KozÁK, David BAXTER et Laila WiLliamson, American Museum of Natural History (Anthropological Papers of the American Museum of Natural History, 55-1), New York [traduction portugaise: « Os índios Héta: peixe em lagoa seca », Boletim do Instituto Histórico, Geográfico e Etnográfico Paranaense, 38, 1981, p. 9-120].

2000 The Muse of History and the Science of Culture, Kluwer Academic/Plenum Publishers, New York.

2003 Evolutionism in Cultural Anthropology. A Critical History, Westview Press, Boulder.

2004 In Solemn Conclave, AuthorHouse, Bloomington (Indiana) [roman sur les manœuvres politiques au sein du Collège des cardinaux lors de l'élection d'un pape].

2006 Diary of a Football Handicapper, Football House, Bloomington (Indiana).

2010 The Evolution of the Human Mind from Supernaturalism to Naturalism. An Anthropological Perspective, Eliot Werner Publications, Inc, New York.

2018 The Checkered History of the Circumscription Theory, AuthorHouse, Bloomington (Indiana).

2019 The Making of an Exhibit Hall: Bringing to Life Amazonian Indian Culture, AuthorHouse, Bloomington (Indiana).

\section{Ouvrages édités}

1960 Essays in the Science of Culture in Honor of Leslie A. White, in celebration of his sixtieth birthday and his thirtieth year of teaching at the University of Michigan, co-édité avec Gertrude E. Dole, Thomas Y. Crowell, New York.

1967 The Evolution of Society. Selections from Herbert Spencer's Principles of Sociology, introduction de Robert L. Carneiro, University of Chicago Press, Chicago.

* M. BARnes : American Museum of Natural History [monica@andeanpast.org] ; Ph. ERIKSON : Université Paris Nanterre, centre EREA du LESC (UMR 7186) [erikson@ parisnanterre.fr]. 
1987 Ethnological Essays by Leslie A. White, co-édité avec Beth Diluingham, introduction de Beth Dillingham et Robert L. Carneiro, University of New Mexico Press, Albuquerque.

2004 The Early State, its Alternatives and Analogues, co-édité avec Leonid GRININ, Dmitri Bondarenko, Nickolay Kradin et Andrey Korotayev, 'Uchitel' Publishing House, Volgograd.

2008 "Modern Capitalist Culture » by Leslie A. White, co-édité avec Ben URISH et Burton J. Brown, avant-propos de Robert L. Carneiro, Ben Urish et Burton J. Brown, Left Coast Press, Walnut Creek (CA).

2011 Evolution. Cosmic, Biological, and Social, co-édité avec Leonid Grinin, Andrey Korotayev et Fred SpIER, 'Uchitel' Publishing House, Volgograd.

\section{Ethnographie kuikuru}

1956-1958 « Extra-marital sex freedom among the Kuikuro Indians of Mato Grosso », Revista do Museu Paulista (São Paulo), 10, p. 135-142.

1957a Subsistence and Social Structure: an Ecological Study of the Kuikuru Indians, thèse de doctorat non-publiée, University of Michigan, Ann Arbor.

$1957 b$ « La cultura de los indios kuikuros del Brasil central. La economía de subsistencia », Runa. Archivo para la Ciencias del Hombre (Buenos Aires), 8, p. 169-186.

1958 «A mechanism for mobilizing labor among the Kuikuru of Central Brazil» avec Gertrude E. Dole, Transactions of the New York Academy of Sciences, Series II, vol. 21, p. 58-60.

1960 «Slash-and-burn agriculture: a closer look at its implications for settlement patterns », in Anthony F. C. Wallace (dir.), Men and Cultures. Selected Papers of the 5th International Congress of Anthropological and Ethnological Sciences (Sept. 1956), University of Pennsylvania Press, Philadelphia, p. 229-234.

1961 «Slash-and-burn cultivation among the Kuikuru and its implications for cultural development in the Amazon Basin », in Johannes Wilbert (dir.), The Evolution of Horticulture Systems in Native South America. Causes and Consequences. Antropológica, Sociedad de Ciencias Naturales La Salle (Supplement Publication, 2), Caracas, p. 47-67 [repris: in Daniel R. Gross (dir.), Peoples and Cultures of Native South America. An Anthropological Reader, American Museum of Natural Story, New York, 1973, p. 98-125; in Patricia J. Lyon (dir.), Native South Americans. Ethnology of the Least Known Continent, Little, Brown and Company, Boston, 1974, p. 122-132; in Yehudi A. Cohen (dir.), Man in Adaptation. The Cultural Present, Aldine Publishing Company in Environmental Anthropology, Chicago, 1974, p. 131-145 et in Michael R. Dove et Carol Carpenter (dir.), A Historical Reader, Blackwell Publishing, Malden (MA), 2008, p. 249-253].

1976 « The afterworld of the Kuikuru Indians », in Ronald K. Wetherington (dir.), Colloquia in anthropology, Fort Burgwin Research Center, Dallas, vol. 1, p. 3-15.

1977 «Recent observations of shamanism and witchcraft among the Kuikuru Indians of Central Brazil », Annals of the New York Academy of Science, 293, p. 215-228. 
1978 « The knowledge and use of rain forest trees by the Kuikuru Indians of Central Brazil », in Richard I. Ford (dir.), The Nature and Status of Ethnobotany, Museum of Anthropology, University of Michigan (Anthropological Papers, 67), Ann Arbor, p. 201-216.

1983 «The cultivation of manioc among the Kuikuru of the Upper Xingú », in Raymond B. Hames et William T. Vickers (dir.), Adaptive responses of native Amazonians, Academic Press, New York, p. 65-112.

1986 «Uso do solo e classificação da floresta (Kuikúro) », in Berta G. Ribeiro (dir.). Etnobiologia, Vozes (Suma Etnológica Brasileira, 1), Petrópolis, p. 47-56.

1989a «To the village of the jaguars: the master myth of the upper Xingú », Antropológica, 72, p. 3-40.

1989b « Amazonia: troubles and witches », Faces, 6 (1), p. 34-36.

1993 «Quarup: a festa dos mortos no Alto Xingu », in Vera Penteado Coelho (dir.), Karl von den Steinen. Um século de antropologia no Xingu, EDUSP/FAPESP, São Paulo, p. 405-429.

1994 «Kuikuru », in Johannes Wilbert, Encyclopedia of World Cultures, G. K. Hall \& Co., Boston, vol. 7, p. 206-209.

2001 «A origem do lago Tahununu, um mito Kuikuro », in Bruna Franchetto et Michael J. Heckenberger (dir.), Os povos do Alto Xingu. História e cultura, UFRJ, Rio de Janeiro, p. 287-292.

2009 «Una visión desde el Xingu », in Diego de Azqueta Bernar (dir.), Los guardianes de la biodiversidad, con la colaboración de Fundación Biodiversidad, Lunwerg S. L., Barcelona, p. 25-26.

\section{Ethnographie amahuaca}

1961 «Little known tribes of the Peruvian Montaña », in Acts of the 34th International Congress of Americanists, Vienna, p. 58-63.

1962 «The Amahuaca Indians of Eastern Peru », Explorers Journal, 40 (6), p. 26-37.

1964a « Shifting cultivation among the Amahuaca Indians of Eastern Peru », in Hans Becher (dir.), Beiträge zur Völkerkunde Südamerikas, Festgabe für H. Baldus, Völkerkundliche Abhandlungen, Hannover, vol. I, p. 9-18 [traduction en espagnol: in Alberto Chirif (dir.), Etnicidad y Ecología, CIPA, Lima, 1979, p. 27-40].

1964b «The Amahuaca and the spirit world», Ethnology, 3, p. 6-11.

1964c «Logging and the patron system among the Amahuaca Indians of Eastern Peru ", Acts of the 35th International Congress of Americanists, Mexico, p. 323-325.

1964d « Science in action: on ethnological tactics », Natural History, 73 (7), p. 58-62.

1970 «Hunting and hunting magic among the Amahuaca Indians of the Peruvian Montaña », Ethnology, 9, p. 331-341 [réimprimé: in Patricia J. Lyon (dir.), Native South Americans. Ethnology of the Least Known Continent, Little, Brown and Company, Boston, 1974, p. 122-132; in Norman Alger (dir.), Many Answers. A Reader in Cultural Anthropology, West Publishing Company, St. Paul (Minnesota), 1974, p. 122-136; in Peter B. Hammond (dir.), Cultural 
and Social Anthropology, Introductory Readings in Ethnology, Macmillan Publishing Company, New York, 1975 (2 éd.), p. 11-18].

1974 " On the use of the stone axe by the Amahuaca Indians of Eastern Peru », Ethnologische Zeitschrift Zürich, 1, p. 107-122.

2009 " The sons of the moon: the Amahuaca version of a widespread Amazonian myth », Amazônica-Revista de Antropologia, 1 (1), p. 54-67.

[n. d.] Unpublished Field Notes, Department of Anthropology, American Museum of Natural History, New York.

\section{Culture matérielle et américanisme}

1962 "The aboriginal cultures of Colombia», in A. Curtis Wilgus (dir.), The Caribbean. Contemporary Colombia, University of Florida Press, Gainesville, p. 22-34.

1963 a «Ecuador: the people», Encyclopaedia Britannica, 7, p. 950-951.

1963b « Ritual of a Bororo Funeral » co-signé avec Vladimír KozÁK et Gertrude E. Dole, Natural History, 72 (1), p. 38-49.

1964 Social Concomitants of Ecological Differences Among Two Amazonian Tribes, Manuscript on file, Department of Anthropology, American Museum of Natural History, New York.

1970 "The transition from hunting to horticulture in the Amazon Basin », Proceedings of the 8th International Congress of Anthropological \& Ethnological Sciences, Science Council of Japan, Tokyo, p. 244-248.

1974 " "Cariape": an instance of the standardization of error in archaeology ", Journal of the Steward Anthropological Society, 6 (1), p. 71-75 [traduction en portugais en 2009: "“Cariapé”: um caso de padronização de erro em arqueologia », Revista de Arqueologia, 22 (1), p. 9-13].

1979a «Tree felling with the stone axe: an experiment carried out among the Yanomami Indians of Southern Venezuela », in Carol Kramer (dir.), Ethnoarchaeology, Columbia University Press, New York, p. 21-58.

1979b «Forest clearance among the Yanomamö, observations and implications », Antropológica, 52, p. 39-76.

1979c « Letter from the field: life with the Yanomamõ », Rotunda (American Museum of Natural History), 3 (1), p. 4.

1979d «Factors favoring the development of political leadership in Amazonia », El Dorado. A Newsletter-Bulletin on South American Anthropology, 4 (1), p. 86-94 [repris in Waud H. Kracke (dir.), Leadership in Lowland South America, Bennington College (South American Indian Studies, 1), Bennington (VT), 1993, p. 4-8].

1982 «Dwellers of the rain forest», in Lost Empires, Living Tribes, National Geographic Society, Washington (DC), p. 283-322.

1986 «Culturas indígenas de la cuenca del Amazonas », in Antonio Perez (dir.), Culturas Indígenas de la Amazonia, Comisión Quinto Centenario, Biblioteca Quinto Centenario, Madrid, p. 61-71. 
1987 «Quantitative Ethnobotany and the Case for Conservation in Amazonia » co-signé avec Ghillian Tolmie Prance, William Balee et Brian Boom, Conservation Biology, 1 (4), p. 296-310.

1988a «Indians of the Amazonian forest », in Julie Sloan Denslow et Christine Padoch (dir.), People of the tropical rain forest, University of California Press, Berkeley, p. 73-86.

1988 b «Letter on Yanomamo Field Work », in Letters Home, 10 (11, Douglas Preston [dir.], « Omni »), p. 48, 50-51.

1988c «A view from the field: the man who invented $21 »$, Rotunda, 13 (8), p. 14.

1989 «The Indians of Amazonia », Faces, 5 (4), p. 26-28.

1992 "The Tasaday "stone axes"-what do they tell us? », in Thomas N. Headland (dir.), The Tasaday controversy. Assessing the evidence, American Anthropological Association, Washington (DC), p. 172-179.

1994 «Traditional peoples of South America; manioc: the reigning crop; the blowgun: the silent, deadly tube », in Goran Burenhult (dir.), The Illustrated History of Humankind, Vol. 5. Traditional Peoples Today, Weldon Owen Pty Ltd/ Bra Boker AB, Australia/Harper, San Francisco, p. 192-209.

$1995 \mathrm{a}$ «The history of ecological interpretations of Amazonia: does Roosevelt have it right? », in Leslie E. Sponsel (dir.), Indigenous Peoples and the Future of Amazonia, University of Arizona Press, Tucson, p. 45-70.

1995 b « To protect and preserve, “AmanaKa'a Amazon network" », Update, 2, p. 7.

1995c «Amazonia, symbolic feathers », Faces, December, p. 6-9.

1998 «Unpalatable Truth », Natural History, 106 (11), p. 7.

2000 "The evolution of the Tipití. A study in the process of invention », in Gary Feinman et Linda Manzanilla (dir.), Cultural Evolution, Contemporary Viewpoints, Kluwer Academic/Plenum Publishers, New York, p. 61-93.

2007 «The mystery of the cotton Tipití », Tipití, 3, p. 29-33.

2008a «Cannibalism, a palatable/unpalatable reality of Amazonia », South American Explorer, 84, p. 8, 10-13, 41-44.

2008 b «Tips and tricks, pitfalls and pleasures of ethnographic fieldwork », in Jack Kelso (dir.), The Tao of Anthropology, University Press of Florida, Gainesville, p. 21-33.

\section{Anthropologie générale et origines de l'état}

1958a «Agriculture and the beginning of civilization », EthnographischeArchäologische Forschungen, 4, p. 22-27.

$1958 \mathrm{~b}$ «An instance of the transport of artifacts by migratory animals in South America », American Antiquity, 24 (2), p. 192-193.

1960 «The culture process », in Gertrude E. Dole et Robert L. Carneiro (dir.), Essays in the Science of Culture in Honor of Leslie A. White, in celebration of his sixtieth birthday and his thirtieth year of teaching at the University of Michigan, Thomas Y. Crowell, New York, p. 145-161.

1962 «Scale analysis as an instrument for the study of cultural evolution », Southwestern Journal of Anthropology, 18, p. 149-169. 
1963 « The application of scale analysis to the study of cultural evolution » avec Stephen F. ToBias, Transactions of the New York Academy of Sciences, 2 (26), p. 196-207.

1966 « On determining the probable rate of population growth during the Neolithic » avec Daisy HiLse, American Anthropologist, 68 (1), p. 177-181.

1967 «On the relationship between size of population and complexity of social organization », Southwestern Journal of Anthropology, 23, p. 234-243.

1968a " Ascertaining, testing, and interpreting sequences of cultural development », Southwestern Journal of Anthropology, 24 (4), p. 354-374.

1968b « Herbert Spencer », in International Encyclopedia of the Social Sciences, MacMillan, London, p. 121-128.

1968c "Culture: cultural adaption », in International Encyclopedia of the Social Sciences, MacMillan, London, p. 551-554.

1969a «The measurement of cultural development in the Ancient Near East and in Anglo-Saxon England » avec Daisy HiLse, Transactions of the New York Academy of Sciences, 2 (31), p. 1013-1023.

$1969 \mathrm{~b}$ « Scale analysis, evolutionary sequences, and the rating of cultures », in Raoul Naroll et Ronald Cohen (dir.), A Handbook of Method in Cultural Anthropology, The Natural History Press, Garden City, p. 833-871.

1970a «A theory of the origin of the state », Science, 169 (3947), p. 733-738 [traduction allemande: "Eine Theorie zur Entstehung des Staates », in Klaus Eder (dir.), Die Entstehung von Klassengesellschaften. Ein Beitrag zu einer Theorie sozialer Evolution, Suhrkam, Frankfurt-am-Main, 1973, p. 153-175].

1970 b « Letter to the Editor (about the role of non-human transportation in the rise of the state) », Science, 170 (3961), p. 931.

1970c «Quantitative law in anthropology », American Antiquity, 35, p. 492-494.

1970d «Forward», in Keith F. Otterbein, The Evolution of War, HRAF Press, New Haven.

1972a «From autonomous villages to the state, a numerical estimation », in Brian Spooner (dir.), Population Growth. Anthropological Implications, MIT Press, Cambridge, p. 64-77.

1972b «Quantitative law defended », American Antiquity, 37, p. 449-450.

1972c «The devolution of evolution », Social Biology, 19 (3), p. 248-258.

$1973 \mathrm{a}$ «Structure, function, and equilibrium in the evolutionism of Herbert Spencer », Journal of Anthropological Research, 29, p. 77-95.

1973b «Classical evolution », in Raoul Naroll et Frada Naroll (dir.), Main currents in cultural anthropology, Prentice Hall, New York, p. 57-121.

1974a «A reappraisal of the roles of technology and organization in the origin of civilization », American Antiquity, 39 (2), p. 179-186.

$1974 b$ « The four faces of evolution », in John J. Honigmann (dir.), Handbook of Social and Cultural Anthropology, Rand McNally \& Company, Chicago, p. 89-110.

1978a «Political expansion as an expression of the principle of competitive exclusion ", in Ronald Cohen et Elman R. Service (dir.), Origins of the State. The Anthropology of Political Evolution, Institute for the Study of Human Issues, Philadelphia, p. 205-223. 
1978b «Legalized football wagering, an alternative approach », Gambling Times (Los Angeles), 2 (8), p. 66-67, 90, 93.

1979 «Leslie Alvin White », in International Encyclopedia of the Social Sciences, Biographical Supplement, The Free Press, New York, vol. 18, p. 803-807.

1981a «The chiefdom: precursor of the state », in Grant D. Jones et Robert R. Kautz (dir.), The Transition to Statehood in the New World, Cambridge University Press, Cambridge, p. 37-79.

1981 « «erbert Spencer as an anthropologist », The Journal of Libertarian Studies, 5 (2), p. 153-210.

1982 "Successive reequilibrations as the mechanism of cultural evolution », in William C. Schieve et Peter M. Allen (dir.), Self-Organization and Dissipative Structures. Applications in the Physical and Social Sciences, University of Texas Press, Austin, p. 110-115.

1984 Origin Myths, American Anthropological Association (Evolution Brochure, 2), Washington (DC).

1986a «On the relationship between size of population and complexity of social organization », Journal of Anthropological Research, 42, p. 355-364.

1986b « Back to evolution: an interview with anthropologist Robert Carneiro », Rotunda (American Museum of Natural History), 11 (2), p. 4-5.

1987 a "The evolution of complexity in human societies and its mathematical expression », International Journal of Comparative Sociology, 28, p. 111-128.

1987 « « Village splitting as a function of population size », in Leland Donald (dir.), Themes in Ethnology and Culture History. Essays in Honor of David F. Aberle, Archana Publications, Meerut (India), p. 94-124.

1987c «Further Reflections on Resource Concentration and Its Role in the Rise of the State », in Linda Manzanilla (ed.), Studies of the Neolithic and Urban Revolutions. The V. Gordon Childe Colloquium, BAR (British Archaeological Reports, International Series, 349), Oxford, p. 245-260.

1988a «Reflexiones adicionales sobre la concentración de recursos y su papel en el surgimiento del estado », in Linda Manzanilla (ed.), Coloquio V. Gordon Childe, Universidad Nacional Autónoma de México, p. 265-281.

1988 b "The circumscription theory: challenge and response », American Behavioral Scientist, 31, p. 497-511 (Entire issue devoted to Circumscription and the Evolution of Society).

1988c «Reflexiones sobre el origen del estado », Agora. Papeles de Filosofía (Universidad de Santiago de Compostela, Spain), 5, p. 5-20.

1989 «Patterns of predynastic settlement location, social evolution, and the circumscription theory » co-signé avec Kathryn BARD, Cahiers de recherches de l'Institut de Papyrologie et d'Egyptologie de Lille, 8 (« Sociétés urbaines en Égypte et au Soudan »), p. 15-23.

1990a «Chiefdom level warfare as exemplified in Fiji and the Cauca Valley », in Jonathan Haas (dir.), The Anthropology of War, Cambridge University Press, Cambridge, p. 190-211.

1990b « The evolution of law », Faces, 7 (2), p. 4-8. 
1991a « The nature of the chiefdom as revealed by Evidence from the Cauca Valley of Colombia », in A. Terry Rambo et Kathleen Gillogly (dir.), Profiles in Cultural Evolution. Papers from a Conference in Honor of Elman R. Service, University of Michigan (Anthropological Papers, Museum of Anthropology, 85), Ann Arbor, p. 167-190 [originellement intitulé The Ecological Basis of Amazonian Chiefdom et parfois cité comme tel].

1991b « Herbert Spencer », in Christopher Winters (dir.), International Dictionary of Anthropologists, compilé par Library-Anthropology Reserve Group (LARG), Garland Publishing, New York/London, p. 655-656.

1991c « Leslie A. White », in Christopher Winters (dir.), International Dictionary of Anthropologists, compilé par Library-Anthropology Reserve Group (LARG), Garland Publishing, New York/London, p. 753-754.

1992a «Point counterpoint: ecology and ideology in the development of new world civilizations », in Arthur A. Demarest et Geoffrey W. Conrad (dir.), Ideology and Pre-Columbian Civilizations, School of American Research Press, Santa Fe (NM), p. 175-203.

1992 b « The role of natural selection in the evolution of culture », Cultural Dynamics, 5, p. 113-140.

1992c «The role of warfare in political evolution: past results and future projections ", in Giorgio Ausenda et Giovanni Ausenda (dir.), Effects of War on Society, Center for Interdisciplinary Research on Social Stress, San Marino, p. 87-102.

1993 «Coltivatori, società di », Enciclopedia delle Scienze Sociali (Rome), 2, p. 85-90.

1994 «War and peace: alternating realities in human history », in Stephen P. Reyna et Richard Erskine Downs (dir.), Studying War, Anthropological Perspectives, Gordon and Breach, Langhorne (PA), p. 3-27.

1995 «Godzilla meets new age anthropology: facing the post-modernist challenge to a science of culture », Europaea (Italy), 1, p. 3-22 [traduction en espagnol en 1998: «El desafío posmoderno a la ciencia de la cultura », Anuario IEHS (Instituto de Estudios Historico-Sociales), 13, p. 419-433; repris dans Robert L. Welsch et Kirk M. Endicott (dir.), Taking Sides. Clashing Views in Cultural Anthropology, McGraw-Hill Contemporary Learning Series, Dubuque (Iowa), 2005 ( $2^{\mathrm{e}}$ ed.), p. 14-24.]

1996a «Cultural Evolution », in David Levinson et Melvin Ember (dir.), Encyclopedia of Cultural Anthropology, sponsorisé par Human Relations Area Files, Yale University, Henry Holt \& Co, New York, p. 271-277.

1996 b «Elman R. Service, 1915-1996», Europaea, 2, p. 145-146.

1997a « Human history: a domain of competing perspectives », Europaea, 3 (2), p. 9-32.

1997b « A rapid method of archeological seriation », Anthropological Science, 105 (3), p. 149-158.

1998 «What happened at flashpoint? Conjectures on chiefdom formation at the very moment of conception », in Elsa M. Redman (dir.), Chiefdoms and Chieftaincy in the Americas, University Press of Florida, Gainesville, p. 18-42. 
1999 «Leslie Alvin White », in John A. Garrity et Marc C. Carnes (dir.), American National Biography, Oxford University Press, New York, vol. 23, p. 230-232.

2000a «The transition from quantity to quality: a neglected causal mechanism in accounting for social evolution », in Proceedings of the National Academy of Sciences, 97, p. 12926-12931.

2000b « Process vs. stages: a false dichotomy in tracing the rise of the state », in Nikolay Kradin, Andrey Korotayev, Dmitri Bondarenko, Victor de Munck et Paul Wason (dir.), Alternatives of Social Evolution, Far Eastern Branch of the Russian Academy of Sciences, Vladivostok, p. 52-58.

2000c « Stellar evolution and social evolution: a study in parallel processes », Journal of the Steward Anthropological Society, 28, p. 1-23 [republié dans Leonid Grinin, Robert L. Carneiro, Andrey Korotayev et Fred Spier (dir.), Evolution. Cosmic, Biological, and Social, 'Uchitel' Publishing House, Volgograd, 2011, p. 66-81].

2001 «The price of a marriage bed », in Terry Stocker (dir.), Incidents, Franklin Pub., Tempe, Arizona, p. 252-257.

2002a «Herbert Spencer's Principles of Sociology: a centennial retrospective and appraisal » avec Robert G. PERrin, Annals of Science, 59 (3), p. 221-261.

$2002 \mathrm{~b}$ « The tribal village and its culture: an evolutionary stage in the history of human society », in William A. Parkinson (dir.), The Archaeology of Tribal Societies, International Monographs in Prehistory, Ann Arbor, MI, p. 34-52.

2004a "Can anthropology be made a science? A retrospective glance », Ethnos (Sweden), 69, p. 268-288.

2004b «The political unification of the world: whether, when, and how. Some speculations », Cross-Cultural Research, 38, p. 162-177.

2004c «Was the chiefdom a congelation of ideas », in Leonid Grinin, Robert L. Carneiro, Dmitri Bondarenko, Nickolay Kradin et Andrey Korotayev (dir.), The early state, its alternatives and analogues, 'Uchitel' Publishing House, Volgograd, p. 28-45.

2004d «Leslie A. White», in Sydel Silverman (dir.), Totems and Teachers. Key Figures in the History of Anthropology, Altamira Press, Walnut Creek, p. 151-173.

2004e «The classical foundations of cultural evolutionism », Shi Lin (Historical Review), 1 (Serial 76), p. 1-12 (in Chinese) (Beijing).

2005a «The influence of Herbert Spencer on the world of letters », in Regna Darnell et Frederick W. Gleach (ed.), History of Anthropology Annual, University of Nebraska Press, Lincoln, vol. 1, p. 246-270.

2005 b «From autonomous villages to the state: an irresistible trend in the grand sweep of human history », General Semantics Bulletin, 72, p. 15-19.

2005c «Prologue », in The Science of Culture by Leslie A. White, Clinton corners, Percheron Press, New York, p. v-xxiii.

2006a «Should anthropology stop trying to model itself on the natural sciences? Yes: Clifford Geertz; No: Robert Carneiro », in Robert L. Welsch et Kirk M. Endicott (dir.), Taking Sides. Clashing Views in Cultural Anthropology, McGraw-Hill (Contemporary Learning Series), Dubuque (IA), [2e éd.], p. 14-24. 
2006b «Craig Morris » co-signé avec Joyce Marcus, Anthropology News, 47 (8), p. 29.

2007a «A base ecológica dos cacicados amazônicos » avec Denise Pahl SchaAn, Revista de Arqueologia, 20 (1), p. 117-154.

$2007 \mathrm{~b}$ «What role does population pressure play in the evolutionary dynamics of Marvin Harris? », in Lawrence A. Kuznar et Stephen K. Sanderson (dir.), Studying Societies and Cultures. Marvin Harris's Cultural Materialism and Its Legacy, Paradigm Publishers, Boulder/London, p. 230-238.

2007c "Foreword", in Max Ostrovsky, Y=Arctg X; The Hyperbola of the World Order, University Press of America, Inc. Lanham, Md., p. ix-xi.

2007d «Foreword» co-signé avec Burton J. Brown, in Leslie A. White, The Evolution of Culture, Left Coast Press, Walnut Creek (CA), p. ix-viii.

2008 «Excavación de una cueva en la provincia de Matanzas », Cuba Arqueológica. Revista Digital de la Arqueologia de Cuba y del Caribe (Havana), 1 (1), p. 32-34.

2009 « There is no archaeology without ethnology and vice versa », in Lourdes Dominguez, Pedro Paulo A. Funari, Aline Vieira de Carvalho et Gabriella Barbosa Rodrigues (dir.), Desafios da arqueologia. Depoimentos, Habilis Editoria, Erechim, Rio Grande do Sul, Brazil, p. 72-75.

2010 «Pauketat's chiefdoms and other archaeological delusions: a challenge to social evolution », Social Evolution \& History (Moscow), 9 (1), p. 135-165, suivi d'une réponse à la réponse de Pauketat, p. 172-176.

2011 «Introduction. Evolutionary megaparadigms: potential, problems, perspectives » avec Leonid GrININ et Fred SPIER, in Leonid Grinin, Robert L. Carneiro, Andrey Korotayev et Fred Spier (dir.), Evolution. Cosmic, Biological, and Social, 'Uchitel' Publishing House, Volgograd, p. 5-29.

2012a «The studied avoidance of war as an instrument of political evolution », in Richard Chacon et Rubén Mendoza (dir.), The Ethics of Anthropology and Amerindian Research. Reporting on environmental degradation and warfare, Springer, New York, p. 361-366.

2012 b « The circumscription theory: a clarification, amplification, and reformulation », Social Evolution \& History, 11 (2), p. 5-30.

2012c «Answers to critiques », Social Evolution \& History, 11 (2), p. 131-190.

2013 «Reminiscences of a stalwart adversary », Andean Past, 11, p. 7-14.

2014 "Introduction », in An Ethnography of England in the Year 1685, Being the Celebrated Third Chapter of Thomas Babington Macaulay's History of England, Eliot Werner Publications, Inc., Clinton Corners (NY), p. i-xii.

\section{Comptes-rendus et commentaires}

1955 Compte-rendu de «Jungle Quest, by Edward Weyer Jr. », American Anthropologist, 57 (5), p. 1070-1071.

1958 Compte-rendu de « The Trumai Indians of Central Brazil, by Robert F. Murphy and Buell Quain » co-signé avec Gertrude Dole, American Anthropologist, 58 (5), p. 747.

1957 Compte-rendu de « Notas de viagem ao rio Paru de Leste, by José Cândido de Melo Carvalho », American Anthropologist, 259 (1), p. 172. 
1959 Compte-rendu de «The Trumai Indians of Central Brazil, by Robert F. Murphy and Buell Quain », Revista do Museu Paulista (São Paulo) n.s., 11, p. 265-272.

1960a Compte-rendu de «The Evolution of Culture, by Leslie A. White », Natural History, 69 (7), p. 5-6.

1960b Compte-rendu de « The Incas of Pedro de Cieza de León, translated by Harriet de Onis and edited by Victor WolfgangVon Hagen », Natural History, 69 (7), p. 5-6.

1962 Compte-rendu de «Areas Culturais Indigenas do Brasil; 1900-1959, by Eduardo Galvão », American Anthropologist, 64 (3), p. 653.

1964 Compte-rendu de "Evolution in the Arts and Other Theories of Culture History, by Thomas Munro », American Anthropologist, 66 (6), p. 1399-1402.

1966a Compte-rendu de «Studies in the Religion of the South-American Indians East of the Andes, by Rafael Karsten, Arne Runeberg, and Michael Webster », American Anthropologist, 68 (2), p. 557-558.

$1966 \mathrm{~b}$ Compte-rendu de « The Savage and the Innocent, by David Maybury-Lewis », Ethnohistory, 13, p. 194-195.

1968 Compte-rendu de « The Cocaine Eaters, by Brian Moser and Donald Tayler », American Anthropologist, 70 (3), p. 582-583.

1969 Commentaires sur « Historical Inferences from Guttman Scales. The Return of Age-Area Magic, by Theodore D. Graves, Nancy B. Graves, and Michael J. Kobrin », Current Anthropology, 10 (4), p. 327-328.

1969b Présentation de « Contact with the Stone Age, by Ivan L. Schoen », Natural History, 78 (1), p. 10-18, 66-67.

1970 Compte-rendu de « Classification of South American Indian Languages, by Čestmír Loukotka and Johannes Wilbert (eds.) », American Anthropologist, 72 (3), p. 686-688.

1971 Compte-rendu de «The Upper Amazon, by Donald Lathrap », American Journal of Archaeology, 75 (2), p. 238-239.

1972 Présentation de « Stone Age Revisited, by Vladimír Kozák », Natural History, 81 (1), p. 14, 16, 18-22, 24.

1974 Commentaires sur « The Evolutionary Theories of Charles Darwin and Herbert Spencer, by Derek Freeman », Current anthropology, 15 (3), p. 222-223.

1976 Compte-rendu de « Tribes of the Amazon Basin in Brazil, by Edwin Brooks, René Fuerst, John Hemming, and Francis Huxley », American Anthropologist, 78 (4), p. 942.

1977a Commentaires sur «Shifts in Production and Organization. A ClusterInteraction Model, by Barbara J. Price », Current Anthropology, 18 (2), p. 222-223.

1977b Compte-rendu de « The Noble Savages, by Bryan Wilson », American Notes and Queries, 16, p. 47-48.

1978 Commentaires sur « Food Taboos, Diet, and Hunting Strategy. The Adaptation to Animals in Amazon Cultural Ecology, by Eric B. Ross », Current Anthropology, 19 (1), p. 19-20. 
1979a Compte-rendu de « Carib-Speaking Indians. Culture, Society and Language, by Ellen B. Basso (ed.) », American Anthropologist, 81 (3), p. 666-667.

1979b Compte-rendu de «War, Its Causes and Correlates, by Martin H. Nettleship, R. Dale Givens, and Anderson Nettleship » et «Discussions on War and Human Aggression by R. Dale Givens and Martin Nettleship », American Anthropologist, 81 (1), p. 187-188.

1979c « Julian Steward and the evolution of culture », compte-rendu de « Julian H. Steward. Evolution and Ecology, by Jane C. Steward and Robert F. Murphy (eds.) », Reviews in Anthropology, 6, p. 287-300.

1979d «The causal analysis of the rise of the state ", réponse à « On Price and Carneiro on Causality, by Thomas Bagatzky », Current Anthropology, 20 (1), p 156-157.

1980a «Chimera of the Upper Amazon », in Richard de Mille (dir.), The Don Juan Papers, Further Castaneda Controversies, Ross-Erikson, Santa Barbara, p. 94-98 [compte-rendu critique de Córdova-Rios Manuel et Frank Bruce Lamb, Wizard of the Upper Amazon, Atheneum, New York, 1971].

1980b «Foreword », in Wen-Shan Huang, An Introduction to Culturology, South Sky Book Company, Hong Kong, p. viii-x.

1982 Commentaires sur «Reductionism in Cultural Ecology. The Amazon Case, by Allen Johnson », Current Anthropology, 23 (4), p. 418-419.

1984 Compte-rendu de « The Evolution of the Prehistoric State, by Jonathan Haas », Ethnohistory, 31 (3), p. 213-214.

1985 Commentaires sur « Darwinian selection, symbolic variation, and the evolution of culture, by David Rindos », Current anthropology, 26 (1), p. 77-78.

1986 «Who are the Kayapo? (Letter to the Editor), Natural History, 95 (4), p. 4.

1987 "Cross-Currents in the theory of state formation », compte-rendu de «Development and Decline. The Evolution of Sociopolitical Organization, by Henri J. M. Claessen, Pieter Van De Velde and M. Estellie Smith », American Ethnologist, 14 (4), p. 756-770.

1988a «Back Eddies among the cross-currents: a reply to Claessen and Van De Velde », American Ethnologist, 15 (4), p. 782-783.

1988 b Compte-rendu de «Victorian Anthropology, by George W. Stocking, Jr. », American Anthropologist, 90 (1), p. 232-233.

1990 Compte-rendu de «The Evolution of Human Societies, by Allen W. Johnson and Timothy Earle », Ethnohistory, 37 (1), p. 105-107.

1991 « Destruction of an Unreconstructed Constructionist », Anthropology News, 32, p. 3.

1992a «The Calusa and the Powhatan, native chiefdoms of North America », compterendu de «The Evolution of the Calusa. A non-agricultural Chiefdom on the Southwest Florida Coast, by Randolph J. Widmer » et « The Powhatan Indians of Virginia. Their Traditional Culture, by Helen C. Rountree », Reviews in Anthropology, 21 (1), p. 27-38.

1992b Compte-rendu de « The Gift of Birds. Featherwork of Native South American Peoples, by D. Reina and Kenneth Kensinger (eds.) », Museum Anthropology, $16(3)$, p. 68-72. 
1994 Compte-rendu de « War in the Tribal Zone, edited by R. Brian Ferguson and Neil L. Whitehead », Contemporary Sociology, 23, p. 80-81.

1995 Compte-rendu de « Configurations of Power. Holistic Anthropology in Theory and Practice, edited by John S. Henderson and Patricia J. Netherly », Journal of the Royal Anthropological Institute, n.s. 1 (2), p. 440-441.

1996 Compte-rendu de « Herbert Spencer. A Primary and Secondary Bibliography, by Robert G. Perrin », Journal of the Royal Anthropological Institute, 2 (3), p. 563.

1997a Compte-rendu de «Foundations of Social Inequality, T. Douglas Price and Gary M. Feinman (eds.) », American Anthropologist, 99 (1), p. 204-205.

1997b Compte-rendu de «Amazonia. Man and Culture in a Counterfeit Paradise, by Betty J. Meggers », The Quarterly Review of Biology, 72 (2), p. 224-225.

1998 Compte-rendu de « Mississippian Political Economy, by John Muller », Southeastern Archaeology, 17 (2), p. 8.

2000 «The native cultures of the southern continent: an attempted triangulation », compte-rendu de «Indigenous South Americans of the Past and Present, by David J. Wilson ", Latin American Antiquity, 11 (1), p. 89-92.

2002 Compte-rendu de " The Birth of the Gods and the Origins of Agriculture, by Jacques Cauvin », American Antiquity, 67 (3), p. 575-576.

2003 Compte-rendu de « Endangered Edens. Visions of the Amazon, by Candace Slater », Tipiti. Journal of the Society for the Anthropology of Lowland South America, 1, p. 138-139.

2004 Compte-rendu de « From Leaders to Rulers, Jonathan Haas (ed.) », American Anthropologist, 106 (1), p. 191-192.

2005 Compte-rendu de « Leslie A. White. Evolution and Revolution in Anthropology, by William J. Peace ", Journal of the Anthropological Institute, n.s. 11 (3), p. 628-629. 
